\title{
SUITABILITY OF DBELA METHODS AS SEISMIC VULNERABILITY ASSESSMENT FOR BUILDINGS IN KOTA KINABALU, SABAH
}

\author{
Noor Sheena Herayani Harith, Lesley Housten C. Kibata, Abdul Karim Bin Mirasa \\ Faculty of Engineering, Universiti Malaysia Sabah, Jalan UMS, 88400 Kota Kinabalu, Sabah, Malaysia \\ *Corresponding Author Email: elystmy@hotmail.com
}

This is an open access article distributed under the Creative Commons Attribution License, which permits unrestricted use, distribution, and reproduction in any medium, provided the original work is properly cited

\section{ARTICLE DETAILS}

\section{Article History:}

Received 12 November 2017 Accepted 12 December 2017 Available online 1 January 2018

\begin{abstract}
Sabah experienced moderate seismicity in the active fault zones located in Kundasang, Ranau of 6.0 MW within minor damage recorded at Sabah recently. The damage following the earthquake and more than 100 aftershocks affected 61 buildings such as schools, hospital and mosque, 22 roads and 22 slopes. Over the past 114 years, a total of 124 with magnitudes ranging from 2.9 to 6.0 are known to have occurred. The earthquake in Sabah that struck Ranau, carrying a moment magnitude of 6.0 on 5 June recently lasted for 30 seconds. This earthquake was the strongest to affect Malaysia since 1976 in Lahad Datu. The latest thesis in the Sabah region had been carried out in Kundasang, Kudat and two buildings in KK city. The objective was to presents the evaluation of soil sample taken in Kota Kinabalu (KK) city that could possibly subjected to low intensity earthquake effects. The evaluation of determination of the soil amplification factor is used to determine the influence of soil condition on buildings in KK city. With the input motion of Whittier Narrows (6.0 Mw, ts $=0.005 \mathrm{~s}$ ) and KKM Ranau (5.9 Mw, ts $=0.01 \mathrm{~s})$, the analysis of the maximum acceleration for PGA and PSA will be varies with the use on program of NERA and DEEPSOIL V5.1. From the appendixes as shown in appendix, it is known that most of their soils are consisting of a surface alluvium layer varying the thickness in between of approximately $5 \mathrm{~m}$ and $20 \mathrm{~m}$ in refer to some researcher. Most of the soil condition is reviewed that there are soil type of B, C, D and E in according to (Technical Committe B/525, 2005). This study shows that the soil amplification factors for each location in KK city are various with the input motion of $5.9 \mathrm{Mw}$, ts $=0.01 \mathrm{~s}$ and $6.0 \mathrm{Mw}$, ts $=0.005 \mathrm{~s}$.
\end{abstract}

\section{KEYWORDS}

Seismic Vulnerability Assessments, DBELA Methods, Ground Response Analysis

\begin{abstract}
1. INTRODUCTION
Sabah's geological data has much on younger Tertiary sedimentary rocks such as sandstone and shale dominant areas. For example, at the Trusmadi Formation, Ranau has the major cut-slopes were made into the hills with black, carbonaceous shale [1-3]. Other than that, it is also believed that the black shale produced very weak materials on weathering which it cannot sustain even gentle slopes [4]. As the result of major slope failures within the deterioration of material shear strength, time in according to geotechnical engineering study [5]. It is reported that Ranau area has a high tetanised region with heaves at two different localities at the North Slope. The localities have their ground surface of the area are featured with many clusters of large granitic boulders, where there is grey shale (Trusmadi Formation) and red shale (Crocker Formation) which can be refer to figure 1 and figure 2 from the Appendices. It is believed that the Ranau area is unsuitable for construction and therefore it requires very intensive site investigations, thus incurring very high development cost [6].
\end{abstract}

\section{MATERIALS AND METHODS}

Among the materials used in this study include the soil sample data of Standard Penetration Test (SPT) is obtained from the UMS Engineering Administration. Each sample is to be list up the locations in KK district, soil types based on EN 1998-1. There are approximately 20 numbers of soil samples data taken in the whole KK district. The soil classification can be refer based from the Eurocode 8 (EN 1998-1) [4]. The classification of soil type A, B, C, D and E is referring to every soil layer of the sample.

Each soil sample is to be determined of their soil profile by using the program NERA. The input data that is to be needed is the desired maximum acceleration which can be found in the input motion data selected as shown in the table 1.
Table 1: Input motion data obtained from a study [7]

\begin{tabular}{|c|c|c|c|c|c|}
\hline $\begin{array}{c}\text { Input Motion } \\
\text { Name }\end{array}$ & Magnitude & $\begin{array}{c}\text { Distance to } \\
\text { Fault Rupture } \\
\text { (km) }\end{array}$ & $\begin{array}{c}\text { USGS } \\
\text { Site } \\
\text { Class }\end{array}$ & $\begin{array}{c}\text { PGA } \\
\text { (g) }\end{array}$ & $\begin{array}{c}\text { Time } \\
\text { step, Ts } \\
\text { (s) }\end{array}$ \\
\hline $\begin{array}{c}\text { Whittier } \\
\text { Narrows }\end{array}$ & 6.0 & 21.2 & A & 0.186 & 0.005 \\
\hline KKMRanau & 5.9 & 62.6 & A & 0.135 & 0.01 \\
\hline
\end{tabular}

The soil sample information such as the depth of soil layers and the type of soil such as clay, silt, sand and etc are to be computed in the soil profile. The figure 3 from the Appendices shows the soil profile is produced from the computation of NERA program. From the result obtained from the program NERA, the maximum spectral acceleration is known as peak ground acceleration (PGA) is obtained.

Table 2: The output values for the soil sample at the location profile of CBB with program of NERA

\begin{tabular}{rl|}
\hline Location profile $=$ & CBB \\
\hline Number of sublayer $=$ & 2 \\
\hline Ratio of critical Damping (\%) $=$ & 5 \\
\hline Depth at top of sublayer $(\mathrm{m})=$ & 6.970000267 \\
\hline Maximum Spectral Acceleration $(\mathrm{g})=$ & 0.263 \\
\hline Maximum Spectral Velocity $(\mathrm{cm} / \mathrm{s})=$ & 27.25 \\
\hline
\end{tabular}

Hence, the amplification factor is the ratio of PSA and PGA based from a study [2].

$$
\text { Soil amplification factor }=\frac{P S A(g)}{P G A(g)} \quad \text { (Equation 1) }
$$

The interpolation of mapping on the KK district is being computed by using the program of ArcGIS. The map is shows in figure 4 from the Appendices. 


\section{RESULTS AND DISCUSSION}

Table 3: The summary of soil profile and the amplification factor, f for the following locations in KK city.

\begin{tabular}{|c|c|c|c|c|c|c|c|c|}
\hline \multirow[b]{2}{*}{ Profile } & \multirow[b]{2}{*}{ Location } & \multirow[b]{2}{*}{ Bedrock } & \multirow{2}{*}{$\begin{array}{c}\text { Ground } \\
\text { Type }\end{array}$} & \multirow{2}{*}{$\begin{array}{c}\text { PGA } \\
\text { (g) }\end{array}$} & \multicolumn{2}{|c|}{$5.9 \mathrm{Mw}, 0.01 \mathrm{~s}$} & \multicolumn{2}{|c|}{$6.0 \mathrm{Mw}, 0.005 \mathrm{~s}$} \\
\hline & & & & & PSA (g) & f & PSA (g) & f \\
\hline $\mathrm{CBB}$ & $\begin{array}{c}\text { Condominium } \\
\text { Development at Jalan Bukit } \\
\text { Bendera }\end{array}$ & Sandstone & $\mathrm{E}$ & 0.263 & 0.504 & 1.919 & 0.390 & 1.484 \\
\hline DKM & $\begin{array}{l}\text { Development at } \\
\text { Karamunsing }\end{array}$ & Sandstone & C & 0.489 & 0.144 & 0.295 & 0.058 & 0.118 \\
\hline EKM & $\begin{array}{l}\text { Extension \& Conversion of } \\
\text { Existing Shops on Hotel \& } \\
\text { Associated Facilities at } \\
\text { Sadong Jaya, Karamunsing }\end{array}$ & Sandstone & D & 0.585 & 0.345 & 0.589 & 0.779 & 1.330 \\
\hline HTA & $\begin{array}{l}\text { Harbour City at Tj Aru, } \\
\text { Sembulan, Jln Pantai Baru }\end{array}$ & Sandstone & $\mathrm{E}$ & 0.521 & 0.244 & 0.468 & 0.347 & 0.666 \\
\hline HHS & $\begin{array}{l}\text { Hotel Development at Jalan } \\
\text { Haji Saman }\end{array}$ & Sandstone & E & 0.309 & 0.445 & 1.439 & 0.684 & 2.214 \\
\hline MGT & Housing at Mengatal & Sandstone & D & 0.261 & 0.161 & 0.617 & 0.129 & 0.497 \\
\hline HKN & $\begin{array}{c}\text { Housing Development at } \\
\text { Kg Nunton, Adjacent SMK } \\
\text { Kolombong }\end{array}$ & Shale & B & 0.218 & 0.463 & 2.124 & 0.233 & 1.066 \\
\hline KTA & $\begin{array}{l}\text { Kudat Property at } \\
\text { TANJUNG ARU }\end{array}$ & Siltstone & $\mathrm{E}$ & 0.145 & 0.401 & 2.768 & 0.385 & 2.657 \\
\hline LHDK & $\begin{array}{l}\text { Pembinaan Bangunan } \\
\text { LHDN KK }\end{array}$ & Sandstone & $\mathrm{E}$ & 0.187 & 0.290 & 1.552 & 0.250 & 1.342 \\
\hline HKK & $\begin{array}{c}\text { Proposed Commerical } \\
\text { Development \& Corporate } \\
\text { Office at Coastal Highway } \\
\end{array}$ & Gravel & E & 0.215 & 0.058 & 0.272 & 0.048 & 0.222 \\
\hline TA & $\begin{array}{c}\text { Proposed Intergrated } \\
\text { Commercial Development } \\
\text { at Tanjung Aru }\end{array}$ & Silt & E & 0.902 & 0.053 & 0.058 & 0.043 & 0.048 \\
\hline DBKK & $\begin{array}{l}\text { Proposed New 4-Storey } \\
\text { Extension to DBKK HQ } \\
\text { Ofiice Building at Jalan } \\
\text { Bandaran }\end{array}$ & sandstone & D & 0.201 & 0.562 & 2.797 & 0.776 & 3.865 \\
\hline
\end{tabular}

The locations of soil sample are to be discussed that they have various range of $f$ values. From the table 3 , it is known that most of their soils are consisting of a surface alluvium layer varying the thickness in between of approximately $5 \mathrm{~m}$ and $20 \mathrm{~m}$ in refer to a research paper [4]. As most of the locations such as CBB, DKM and HTA are consisting of a surface alluvium layer, there are some locations in KK district with rock or other rock-like geological formation as same as Ranau district [8]. The hypocenter distance (Rhypo) between fault rupture between KK and Ranau are mostly in approximately $60 \mathrm{~km}$ of distance. So, the possibility of the locations at $\mathrm{KK}$ district could prone to earthquake damage with low to medium range of earthquake magnitude.

\section{CONCLUSION}

This research described the study of dynamic soil properties for locations of KK city in Sabah, Malaysia. Ground response analyses were performed using 1-D shear wave propagation analysis. The analysis was performed with the input motion of $5.9 \mathrm{Mw}$, ts $=0.01 \mathrm{~s}$ and $6.0 \mathrm{Mw}$, ts = $0.005 \mathrm{~s}$. In this study, the analysis was performed using nonlinear approach in order to consider the actual nonlinear response of a soil deposit. From the results obtained, the soil amplification factors for each location in KK city are various. These values were produced for each location in KK city in this research that can be used as input for seismic design, land use management, and estimation of potential liquefaction and landslides. The results of ground response analysis show that both the time histories and local soil conditions (soil stiffness, stratigraphy and ground water level) are critical to the results of ground response analysis. Generally, time histories affect the amplitude of peak ground acceleration, whilst the soil conditions influence the frequency content of the spectrum. Therefore, these two subjects should be considered and determined carefully in ground response analyses in further study of this paper.

\section{ACKNOWLEDGEMENT}

The author thanks the unit from Universiti Malaysia Sabah. This support is gratefully acknowledged.

\section{REFERENCES}

[1] Ghafar, M., Ramly, N., Alel, M., Adnan, A., Mohamad, E. T., Yunus, M. Z. M. 2015. A Simplified Method for Preliminary Seismic Vulnerability Assessment of Existing Building in Kundasang, Sabah, Malaysia. Jurnal Teknologi, 72 (3). Https://Doi.Org/10.11113/Jt.V72.4003

[2] Adnan, A., Suradi, S., Selvanayagam, P. N., Darus, Z. 2006. Vulnerability of Public Buildings Subjected to Earthquake by Finite Element Modelling. Proceedings of the 6th Asia-Pacific Structural Engineering and Construction Conference, 5-6, 259-269.

[3] Ismail, R., Adnan, A., Ibrahim, A. 2011. Vulnerability of Public Buildings in Sabah Subjected to Earthquake by Finite Element Modelling. In Procedia Engineering, 20, 54-60. Https://Doi.Org/10.1016/ J.Proeng.2011.11.138
[4] Technical Committe B/525. 2005. Part 1-1: General Rules, Seismic Actions and General Requirements for Structures. In En 1998-1-1: Eurocode 8, Design Provisions for Earthquake Resistance of Structures. Brussels.

[5] Huat, B.B.K., Ali, F.H. 2008. Creep Movement of Natural Slopes in Sabah, East Malaysia. In Landslides in Malaysia: Occurrences, Assessment, Analyses, And Remediation, Pp. 443-448. Serdang: Penerbit Universiti Putra Malaysia.

[6] Golutin, B. 2013. Geological Terrain Mapping of The Ranau Area, Sabah. Technical Papers, 51-61.

[7] Hashash, Y., Groholski, D., Phillips, C., Park, D., Musgrove, M. 2012. Deepsoil 5.1, User Manual and Tutorial. Department of Civil and Environmental Engineering--University of Illinois At Urbana-Champaign.

[8] Esdac. 2017. The Soils of Sabah: Kota Kinabalu. Retrieved April 20, 2017, From Http://Esdac.Jrc.Ec.Europa.Eu/Images/Eudasm/Asia/ Images/Maps/Download/Pdf/My3007_5so. Pdf.

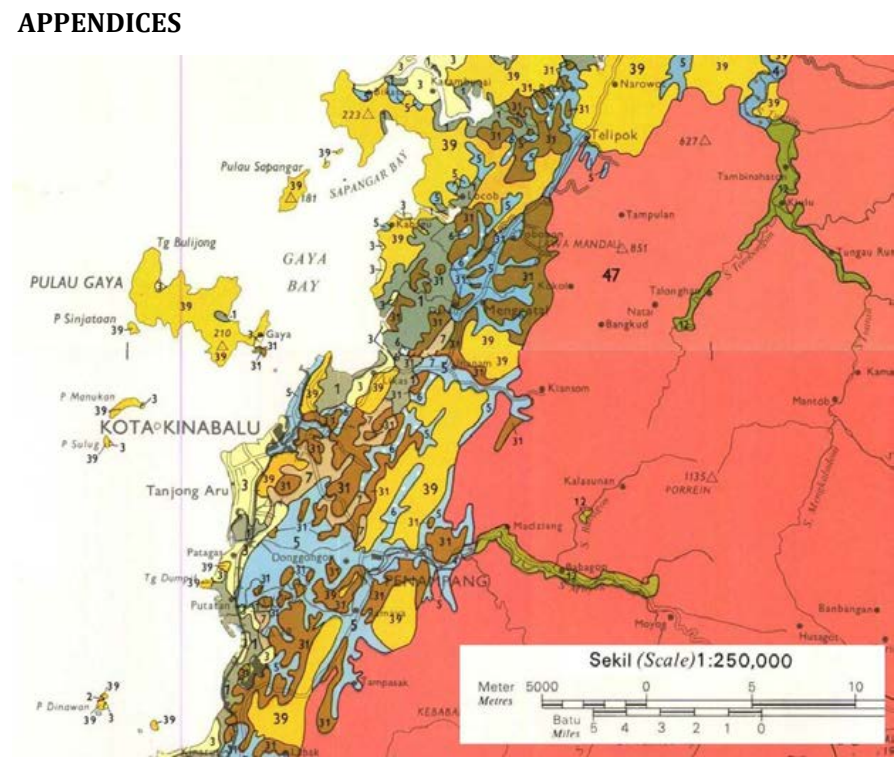

Figure 1: The soils of KK district of Sabah published for Land Resources Division, Overseas Development Administration of England on 1974 [8].

\begin{tabular}{|c|c|c|c|}
\hline Key & Landform & Parent materials & Main soil units \\
\hline 1 & Tidal swamps & $\begin{array}{l}\text { Sulphidic alluvium, sulphidic } \\
\text { peat and alluvium }\end{array}$ & Thionic Fluvisol; Dystric Histosol; Thionic Gleysol \\
\hline 3 & Beaches & Alluvium & $\begin{array}{l}\text { Dystric and Eutric Regosols; Humic, Dystric } \\
\text { and Eutric Gleysols; Glevic Podzzol }\end{array}$ \\
\hline 5 & Floodplains & Alluvium & $\begin{array}{l}\text { Glevic Acrisol; Gleyic Luvisol: Humic, Dystric } \\
\text { and Eutric Gleysols }\end{array}$ \\
\hline 6 & Swamps & Alluvium and peat & $\begin{array}{l}\text { Humic, Dystric and Eutric Gleysols; Dystric } \\
\text { Histosol }\end{array}$ \\
\hline 7 & Swamps & Peat and alluvium & Dystric Histosol; Humic Gleysol \\
\hline 30 & Moderate hills: slopes $>25^{\circ}$ & Mudstone and sandstone & Orthic Acrisol; Dystric Cambisol \\
\hline 31 & $\begin{array}{l}\text { Moderate hills and minor valley floors: } \\
\text { slopes } 0-20^{\circ}\end{array}$ & $\begin{array}{l}\text { Sandstone, mudstone and } \\
\text { alluvium }\end{array}$ & Orthic, Ferric and Gleyic Acrisols \\
\hline 32 & $\begin{array}{l}\text { Moderate hills and minor valley floors: } \\
\text { slopes } 0-20^{\circ}\end{array}$ & $\begin{array}{l}\text { Sandstone, mudstone and } \\
\text { alluvium }\end{array}$ & Ferric, Orthic and Gleyic Acrisols \\
\hline 33 & Moderate hills: slopes $0.20^{\circ}$ & $\begin{array}{l}\text { Mudstone, sandstone and } \\
\text { miscellaneous rocks }\end{array}$ & $\begin{array}{l}\text { Ferric and Orthic Acrisols; Ferric, Chromic and } \\
\text { Orthic Luvisols }\end{array}$ \\
\hline 34 & High hills: slopes $15-25^{\circ}$ & Basic igneous rocks & Ferric Acrisol; Orthic Luvisol \\
\hline 35. & Moderate hills: slopes $10-20^{\circ}$ & $\begin{array}{l}\text { Tuffaceous rocks, mudstone } \\
\text { and sandstone }\end{array}$ & Chromic and Orthic Luvisols: Orthic Acrisol \\
\hline 36 & High hills: slopes $>25^{\circ}$ & $\begin{array}{l}\text { Sandstone, mudstone and } \\
\text { igneous rocks }\end{array}$ & $\begin{array}{l}\text { Ferric Acrisol: Chromic and Orthic Luvisols; } \\
\text { Drstric and Eutric Cambisols }\end{array}$ \\
\hline 37. & Very high hills: slopes $>25^{\circ}$ & Basic igneous rocks & Chromic and Eutric Cambisols \\
\hline 38 & Very high hills: slopes $>25^{\circ}$ & Limestone & Calcic Luvisol; Rendzina \\
\hline 39 & Very high hills: slopes $>25^{\circ}$ & Sandstone and mudstone & Orthic Acrisol; Dystric Cambisol \\
\hline
\end{tabular}

Figure 2: The soil types legend for the KK district of Sabah published for Land Resources Division, Overseas Development Administration of England on 1974 [8]. 

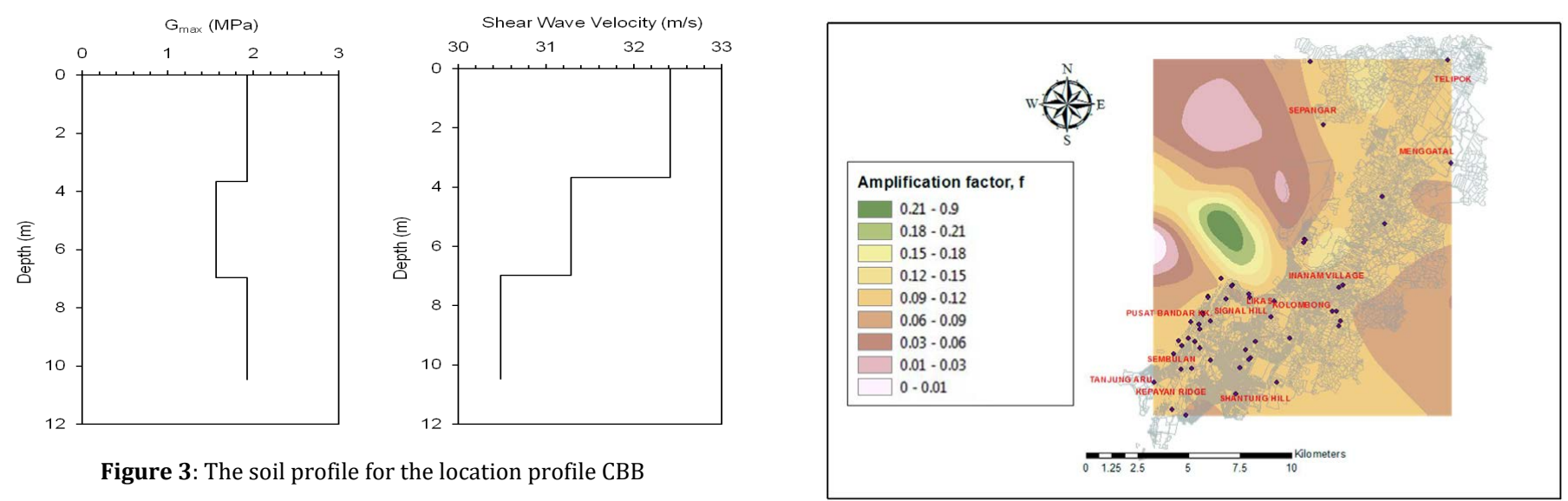

Figure 3: The soil profile for the location profile CBB

Figure 4: Contour of soil amplification factor under Time History and Ground Motion of KKMRanau (5.9 Mw, ts = $0.01 \mathrm{~s}$ ) 